\title{
Molecular Characterisation of Salmonella enterica Serovar Typhi Isolated from Typhoidial Humans
}

\author{
Arunava Das ${ }^{1 *}$, Seenivasan Sree Hari ${ }^{1}$, Umachandran Shalini ${ }^{2}$, Arumugam Ganeshkumar ${ }^{3}$ and Magudeshwaran \\ Karthikeyan ${ }^{4}$ \\ ${ }^{1}$ Department of Biotechnology, Bannari Amman Institute of Technology, \\ Sathyamangalam-638401, Erode District, Tamil Nadu, India. \\ ${ }^{2}$ Centre for Biotechnology, A. C. Tech Campus, Anna University, Chennai-600025, Tamil Nadu, India. \\ ${ }^{3}$ Department of Biological Sciences, BITS, Pilani - K. K. Birla Goa Campus, Zuarinagar, Goa- 403726, India. \\ ${ }^{\mathrm{d} B i o c o n}$ Limited, Electronic City, Bangalore-560100, India. \\ E-mail:drarunavadas@rediffmail.com
}

Received 8 February 2012; received in revised form 30 March 2012; accepted 2 April 2012

\begin{abstract}
Aims: Salmonella enterica serovar Typhi is the major causative agent for typhoidial fever around the globe among human population reported till date. Present research work was carried out for detection and molecular characterisation of Salmonella enterica serovar Typhi isolated from humans with Typhoidial fever by biochemical, phenotypical and virulence gene based polymerase chain reaction (PCR) techniques. The isolated strains were also investigated for antibiotic susceptibility patterns as a control measure.

Methodology and Results: A total of 16 clinical samples were collected from the same numbers of patients $(7 \mathrm{males}$ and 9 females) from Coimbatore, Erode and Salem districts of Tamil Nadu and were processed via broth enrichment methods for isolation and identification of the causative agent $S$. enterica serovar Typhi. Microbiological and biochemical investigations revealed the presence of $S$. Typhi from 16 samples. The biotyping of the isolates showed that all the isolates belonged to biotype IV. The PCR analysis confirmed the presence of invA (Invasion gene, 244bp), tyv (Tyvelose epimerase gene, 615 bp), fliC-d (Phage-1 flagellin gene for d-antigen, $750 \mathrm{bp}$ ) and viaB (Vi antigen gene, 439bp) in all 16 clinical samples. The antibiotic susceptibility test that was carried out among the isolates against 12 antimicrobial agents, showed $100 \%$ resistance to only ampicillin and $100 \%$ sensitivity to carbenicillin, chloramphenicol, clindamycin, gentamycin, kanamycin and tetracycline.

Conclusion, significance and impact of study: This study confirmed the association of virulent strains of $S$. enterica serovar Typhi from Typhoidial fever among human population and suggested that PCR based diagnostic could be very useful for the rapid detection of $S$. Typhi isolates. Present study emphasized the use of antibiotic like chloramphenicol or in combination with other antibiotics for the effective control of $S$. Typhi.
\end{abstract}

Keywords: Salmonella enterica serovar Typhi, antibiogram, PCR, Typhoidial fever

\section{INTRODUCTION}

Salmonella enterica serovar Typhi, an inevitable etiology of sporadic outbreaks of typhoidial fever, which remains as an important public health problem, causes 16 million cases of the disease and about 600,000 deaths, annually, all over the world (Ivanoff and Levine, 1995). It also results in fatal infection among adults and children, if untreated causing bacteraemia and inflammatory destruction of the intestine and other organs (Hirose et al., 2002).

There are nearly 2,000 Salmonella serovars and for those tested so far, all seem to contain invasion gene (inv) which enable the bacteria to invade host cells (Chiu and Ou, 1996). The O antigen gene (tyv) encodes CDP tyvelose epimerase, which converts CDP - paratose to CDP - tyvelose. The tyv gene is present in both serovars Typhi and Paratyphi A, but the tyv gene of serovar
Paratyphi A does not produce active CDP tyvelose epimerase due to the 1-bp deletion which causes the frame shift mutation and converts codon 4 of tyv to a stop codon (Verma and Reeves, 1989). All virulent strains of S. enterica serovar Typhi causing typhoidial fever possess the Vi capsular antigen gene. Thus, the DNA sequence encoding the $\mathrm{Vi}$ antigen, pertaining to the viaB region is useful in developing DNA based diagnostic tests for $S$. enterica serovar Typhi (Hashimoto et al., 1995). The flagellin gene flic encodes the major component of the flagellum which plays a key role for the Type III Secretion system, the most widely used mechanism to secrete proteins from cytoplasm of the bacterial cell (Yonekura et al., 2003) and in case of S. enterica serovar Typhi, the $\mathrm{H}$ antigen gene (fliC-d) ie., phage-1 flagellin gene for $\mathrm{d}$ antigen [H:d] encodes for flagellin (Hirose et al., 2002). Antibiotics such as chloramphenicol has been a choice of drug for the treatment of typhoid fever for about 40 years, but alternative drugs for treatment are now required due to 
the emergence of multi-drug resistant $S$. enterica serovar Typhi showed resistant to ampicillin, chloramphenicol and trimethoprimsulfamethoxazole (Hirose et al., 2001). Geographically, the emergence and spreading of multidrug resistant $S$. enterica serovar Typhi have been reported from developing countries, particularly the Indian subcontinent and Southeast Asia (Chitnis et al., 1999; Rao et al., 1993). The emergences of the drug resistant $S$. Typhi strains possess major challenge in the treatment and prevention of typhoid fever, particularly, in rural India population (Senthilkumar and Prabakaran, 2005). Therefore, it is essential to reappraise the antibiotic sensitivity pattern of the isolates periodically.

In this study, detection and molecular characterisation of S. enterica serovar Typhi isolated from typhoidial human blood samples has been carried out by biochemical, phenotypical and molecular characterisation tools. Present study also determines the antibiotic susceptibility pattern of the $S$. Typhi strains and their prevalence towards the multi-drug resistance for epidemiological study.

\section{MATERIALS AND METHODS}

\section{Sample collection}

Blood specimens were obtained aseptically before the antibiotic therapy from 16 patients $(7$ males and 9 females) with typhoidial fever from various hospitals and clinics situated in Coimbatore, Erode and Salem districts, Tamil Nadu, India during the month of January and February. The epidemiological data sheet from each patient was generated (Table 1). Blood samples were transported in an ice cold container and immediately processed for microbial investigation.

\section{Isolation and identification}

A volume of three to five millilitres of venous blood was inoculated into $30 \mathrm{~mL}$ of brain heart infusion broth (HiMedia, Mumbai). A minimum blood-to-broth ratio of 1 to 10 was maintained. Blood culture broths were incubated at $37^{\circ} \mathrm{C}$ for 7 days. All tubes were examined daily and if any visible growth was observed were then streaked on sheep blood agar followed by streaking on xylose lysine deoxycholate (XLD) agar plates (Hi-Media, Mumbai) and incubated at $37^{\circ} \mathrm{C}$ for $24 \mathrm{~h}$. Bacterial colonies were purified based on the size, shape, colour on XLD agar and patterns of haemolysis on blood agar and were subjected to Gram's staining. Bacterial isolates were identified by standard biochemical tests like motility test, citrate utilization, methyl red and Voges Proskauer test, hydrogen sulphide production, fermentation of mannitol, arabinose, sorbitol, dulcitol, lactose, sucrose and glucose (Holt et al., 1994).

\section{Biotyping of the isolates}

The isolates were investigated for their ability to ferment I- arabinose and xylose. S. enterica serovar Typhi strains can be classified as biotypes I (arabinose ${ }^{-}$, xylose ${ }^{+}$), II (arabinose ${ }^{-}$, xylose ${ }^{-}$), III (arabinose ${ }^{+}$, xylose ${ }^{+}$) and IV (arabinose ${ }^{+}$, xylose ${ }^{-}$) (Kristensen and Henriksen, 1926; Kristensen, 1938).

\section{Scanning electron micrograph}

Isolates were grown on nutrient agar plates and were fixed with Karnovsky's fixative $(\mathrm{pH} 7.3)$ and incubated at 4 ${ }^{\circ} \mathrm{C}$ for $4 \mathrm{~h}$. Samples were washed twice with $0.1 \mathrm{M}$ Sodium Cocodylate buffer (pH 7.4) (Sigma, USA) and incubated at $4{ }^{\circ} \mathrm{C}$ for $15 \mathrm{~min}$ for each wash, post fixed with same mix for $12 \mathrm{~h}$ at $4{ }^{\circ} \mathrm{C}$ and dehydrated in a series of acetone from 30-100 \%, twice in each dehydrating solution for $15 \mathrm{~min}$ at $4{ }^{\circ} \mathrm{C}$. The samples were dried using the drying reagent tetra methyl silane (Sigma, USA) for 15 min at $4^{\circ} \mathrm{C}$ and air dry in air hood for $15 \mathrm{~min}$. The samples were mounted on aluminium stubs, with adhesives taps and sputter coated with carbon for 5 min using a polaron energy beam and examined under the SEM (Jeol-Jem, Japan).

\section{Detection of virulence genes by polymerase chain reaction}

The virulence of the organism was studied by detection of the invasion gene (invA), phage-1 flagellin gene for $d-$ antigen (fliC-d), tyvelose epimerase gene (tyv) and $\mathrm{Vi}$ antigen genes (viaB) by PCR. The invA gene was detected by single gene PCR (Chiu and Ou, 1996), whereas, a multiplex PCR was used to detect the fliC-d, tyv and viaB genes (Hirose et al., 2002). The forward and reverse primer pairs for invA gene of $244 \mathrm{bp}$ were 5 'acagtgctcgttacgacctgaat-3' and 5'-agacgactggtactgatcgataat3' (Chiu and Ou, 1996); fliC-d genes of 750bp were 5'aatcaacaacaacctgcagcg-3' and 5'-gcatagccaccatcaataacc-3' (Hirose et al., 2002); tyv gene of $615 \mathrm{bp}$ were 5'gaggaagggaaatgaagctttt-3' and 5'-tagcaaactgtctcccaccatac-3' (Hirose et al., 2002) and viaB gene of 439bp were 5'gttatttcagcataaggag-3' and 5'-cttccataccacttccg-3' (Hirose et al., 2002) were commercially synthesized (Bangalore Genei, Bangalore). S. enterica serovar Typhi (MTCC 733) and Aeromonas hydrophila (MTCC 646), strains were used as positive and negative controls respectively.

Freshly grown bacterial colonies were suspended in 200 $\mu \mathrm{L}$ of sterile distilled water in a micro centrifuge tube, gently vortexed and boiled for $10 \mathrm{~min}$ in a water bath. Supernatant after centrifugation at $10000 \mathrm{rpm}$ for $5 \mathrm{~min}$ was used as a template DNA. The amplification was carried out in $25 \mu \mathrm{L}$ reaction volume containing $12.5 \mu \mathrm{L}$ of $2 \times$ PCR master mix (Promega, USA) containing $4 \mathrm{mM}$ magnesium chloride, $0.4 \mathrm{mM}$ of deoxynucleotide triphosphates (dNTPs), $0.5 \mathrm{U}$ of Taq DNA polymerase, $150 \mathrm{mM}$ tris-hydrochlroric acid, $\mathrm{pH} 8.5$ (Promega, USA), 1 $\mu \mathrm{M}$ concentration of primers (invA-F and invA-R), $0.1 \mu \mathrm{M}$ concentration of primers (tyv-F, tyv-R, fliC-d-F and fliC-d$\mathrm{R}$ ) and $0.2 \mu \mathrm{M}$ concentration of primers (viaB-F and viaBLane P: Positive control (S. enterica serovar Typhi MTCC 733); 


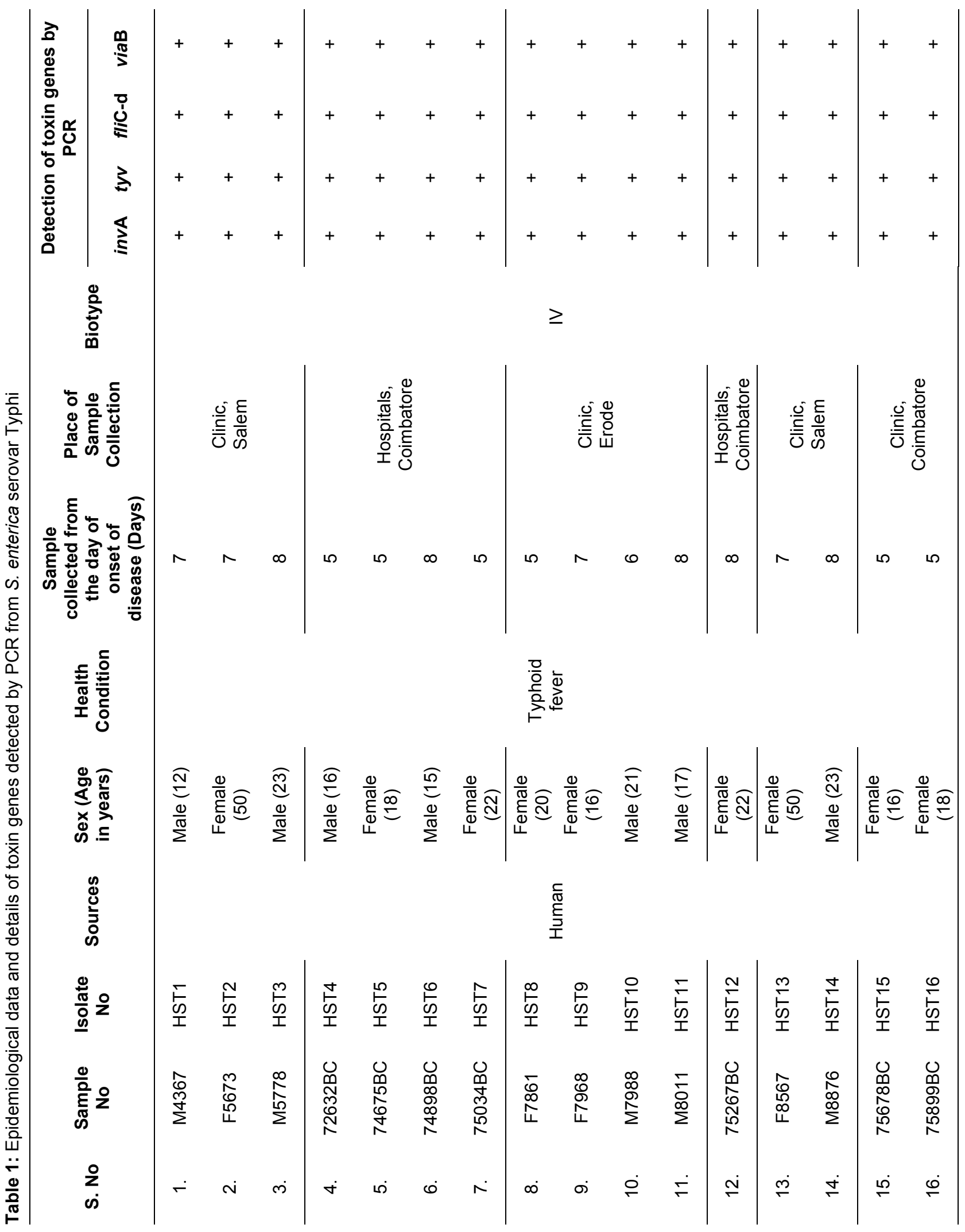




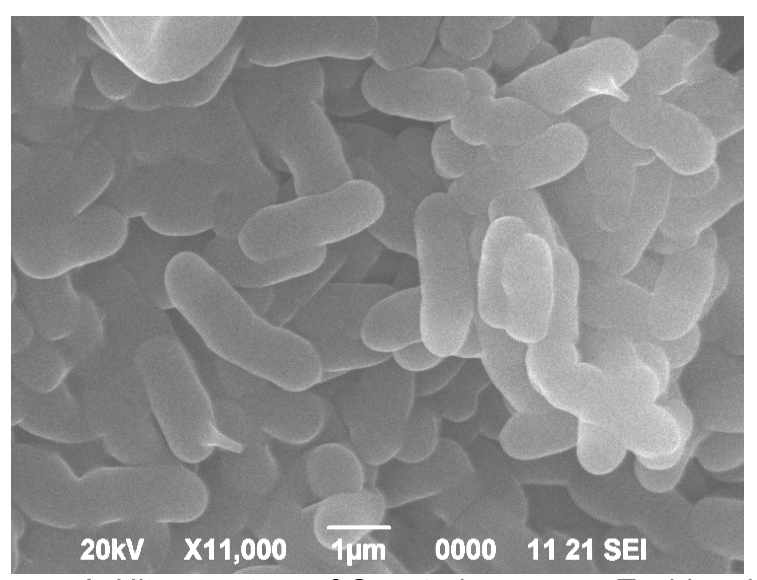

Figure 1: Ultrastructure of $S$. enterica serovar Typhi under $\operatorname{SEM}(11,000 x)$.

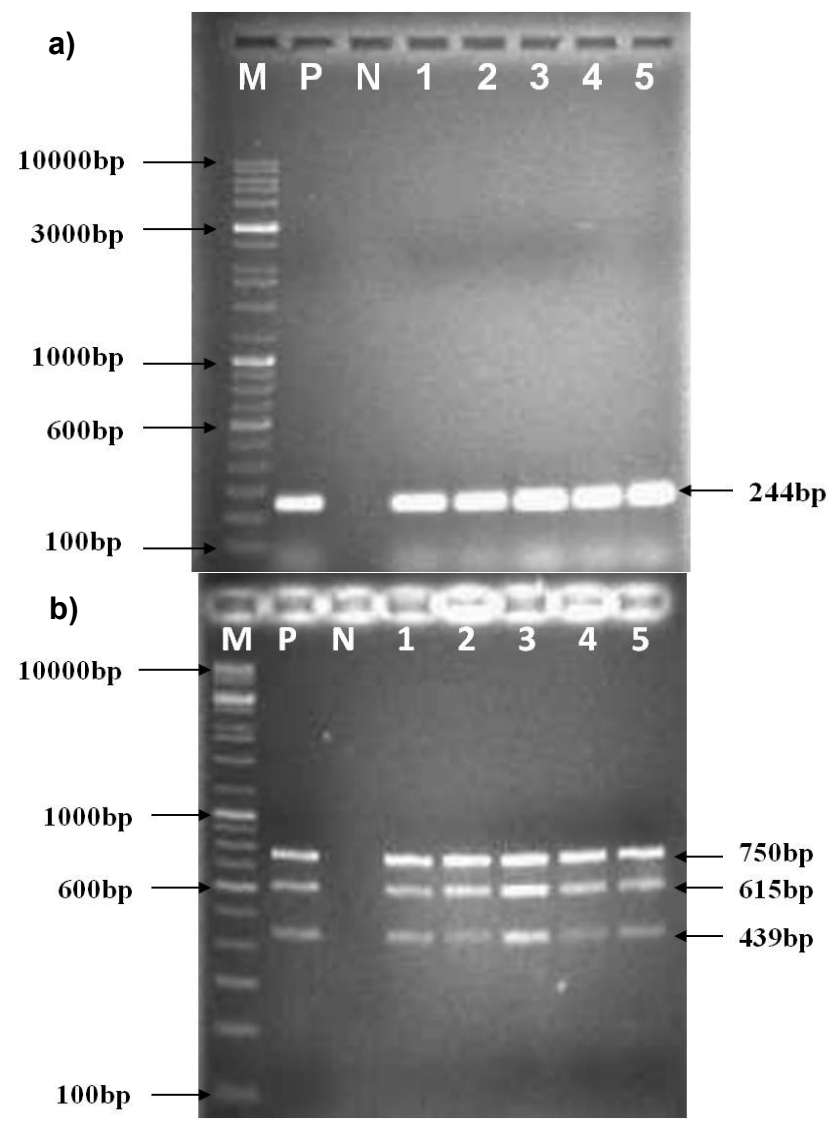

Figure 2: Detection of virulence genes from $S$. enterica serovar Typhi by PCR.

A: Detection of invA (244 bp) gene by PCR

B: Detection of tyv (615 bp), fliC-d (750bp) and viaB (439bp) genes by mPCR

Lane N: Negative control (A. hydrophila MTCC 646);

Lane 1-5: Field isolates positive for virulence genes;

Lane $\mathrm{M}$ : High range DNA rule

$\mathrm{R})$ and $2.5 \mu \mathrm{L}$ of template DNA. The PCR reactions were performed in thermal Cycler (Eppendorf, USA). For the
invA gene after initial denaturation at $94^{\circ} \mathrm{C}$ for $4 \mathrm{~min}$, the amplification cycle had denaturation, annealing and extension at $94^{\circ} \mathrm{C}, 56^{\circ} \mathrm{C}$ and $72{ }^{\circ} \mathrm{C}$ for $30 \mathrm{~s}, 30 \mathrm{~s}$ and 2 min respectively. For fliC-d, tyv and viaB genes after initial denaturation at $95^{\circ} \mathrm{C}$ for $4 \mathrm{~min}$, the amplification cycle had denaturation, annealing and extension at $95^{\circ} \mathrm{C}, 55^{\circ} \mathrm{C}$ and $72^{\circ} \mathrm{C}$ for $30 \mathrm{~s}, 60 \mathrm{~s}$ and $90 \mathrm{~s}$ respectively. Final extension was done at $72^{\circ} \mathrm{C}$ for $10 \mathrm{~min}$. The PCR amplicons $(5 \mu \mathrm{L})$ were electrophoresed in $1.5 \%$ agarose gel in TAE (Trisacetic acid-EDTA, pH 8) buffer, stained with ethidium bromide and observed under gel doc system (Universal Hood, BIORAD, Italy).

\section{Antibiotic susceptibility test}

Antibiotic susceptibility tests were performed by disc diffusion method (Bauer et al., 1996) with little modification. Overnight cultures in peptone water were spread plated on nutrient agar (Hi-media, Mumbai) plates. The antibiotics discs (Hi-media, Mumbai) were purchased and used at the following concentrations: Gentamycin (10 g), Cefuroxime $(30 \mathrm{~g})$, Penicillin-G $(2 \mathrm{U} / \mathrm{mL})$, Nalidixic acid $(30 \mathrm{~g})$, Clindamycin (10 g), Carbenicillin (100 g), Cephalothin $(30 \mathrm{~g})$, Kanamycin $(30 \mathrm{~g})$, Nitrofurantoin (100 $\mathrm{g})$, Tetracyclin (30 g), Ampillicin (10 g) and Chloramphenicol $(30 \mathrm{~g})$. The resistance breakpoints were those defined by the National Committee for Clinical Laboratory Standards (NCCLS, 1999) for Gram negative bacteria. S. enterica serovar Typhi (MTCC 733) and $A$. hydrophila (MTCC 646) were used as controls.

\section{RESULTS}

\section{Isolation and identification}

A visible growth was observed in $\mathrm{BHI}$ broth on $7^{\text {th }}$ day of incubation. The isolates were found non haemolytic on sheep blood agar and showed pink colour colonies with black centre on XLD agar. Glucose, mannitol, L-arabinose and sorbitol were fermented by all isolates. In triple sugar iron slants, the butt and slant turned into yellow and red colour respectively indicating the fermentation of glucose alone and production of acid in the butt. The isolates showed production of hydrogen sulphide and no gas production in TSI. Isolates were positive for oxidase test and methyl red test and negative for indole production, urease production and citrate utilization. All the isolates were found Gram negative, flagellated and motile. Upon detailed bacteriological investigation based on the biochemical tests, 16 isolates were tentatively identified as S. enterica serovar Typhi (Table 1).

\section{Biotyping of the isolates}

All the 16 isolates were able to ferment l-arabinose but not xylose. Thus $S$. enterica serovar Typhi strains were classified as biotype IV (Table 1)

\section{Scanning electron micrograph}

The ultrastructure study of $S$. enterica serovar Typhi in 
SEM was observed to be in clusters of thick rods (Figure 1). The rods were observed to be variable in length; sometimes occured either single or in pairs and occasionally in short chains.

\section{Detection of virulence genes by polymerase chain reaction}

In PCR assay, amplification of virulence genes from all 16 isolates tested with the primers of invA, tyv, viaB and flic$d$ genes resulted fragments of the predicted size at 244 bp, 615 bp, 439 bp and 750 bp respectively (Table 1, Figure 2).

\section{Antibiotic susceptibility test}

In the present study, all the $16(100 \%)$ isolates were found resistant to ampicillin, moderately sensitive to nalidixic acid and nitrofurantoin and sensitive to carbenicillin, chloramphenicol, clindamycin, gentamycin, kanamycin and tetracycline. However, 13 (81.25\%) isolates were also found resistance to cefuroxime, while $11(68.75 \%)$ isolates were found resistant to penicillin-G and cephalothin. The remaining $3(18.75 \%)$ were moderately sensitive to cefuroxime and 5 (31.25\%) isolates were moderately sensitive to penicillin-G and cephalothin (Figure 3, Figure 4).

\section{DISCUSSION}

In the present study, blood samples were collected from 16 patients of age group 12 to 50 years from Coimbatore, Erode and Salem districts, Tamil Nadu, India. All the clinical samples were collected during the month of January and February and this end of dry season was considered to be the peak occurrence season of typhoidial fever (Lin et al., 2000). Infected and healthy carriers were the source of infection and "five Fs" (food, fingers, flies, fomites and faeces) played an important role in the spread of the disease (Old and Threlfal, 1998). All the 16 patients were diagnosed typhoid positive from the fifth to eighth days of onset of disease and the attack rate $14(87.5 \%)$ was significantly higher among the people below 30 years old. Very similar to the present study, higher frequency of detection of typhoid cases from the patients of less than 30 years old were previously reported from Tamil Nadu (Ganeshkumar et al., 2010). All the isolated bacteria produced pink coloured and black centred colonies on XLD plates and were positive for mannitol, l-arabinose, sorbitol, glucose fermentation, methyl red test, indole test, $\mathrm{H}_{2} \mathrm{~S}$ production, citrate utilization, motility, oxidase test and urease activity. The microbiological investigation confirmed the tentative isolation of $S$. enterica serovar Typhi from the clinical cases of typhoid fever from patients were reported earlier (Wain et al., 1998; Ganeshkumar et al., 2010). All the $16(100 \%)$ isolates were classified as biotype IV for fermenting l-arabinose but not xylose. This biotyping have added data to the epidemiological based classification system according to their fermentation ability of sugars and based on other biochemical properties (Kristensen and Henriksen, 1926; Kristensen, 1938).

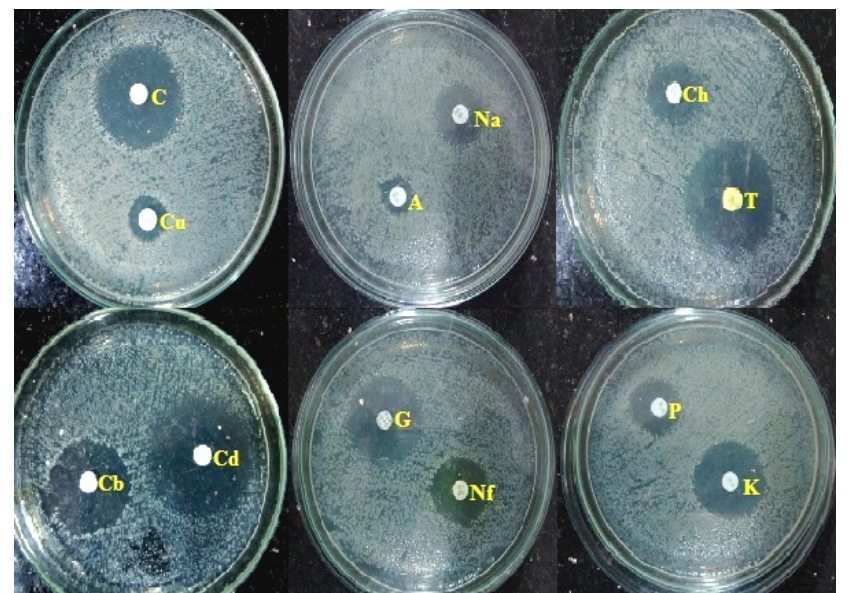

Figure 3: Antibiotic susceptibility of $S$. enterica serovar Typhi.

C: Chloramphenicol $(30 \mu \mathrm{g}), \mathrm{Cu}$ : Cefuroxime $(30 \mu \mathrm{g}), \mathrm{A}$ : Ampillicin $(10 \mu \mathrm{g}), \quad \mathrm{Na}$ : Nalidixic acid $(30 \mu \mathrm{g}), \mathrm{Ch}$ : Cephalothin $(30 \mu \mathrm{g})$, T: Tetracycline $(30 \mu \mathrm{g}), \mathrm{Cb}$ : Carbenicillin $(100 \mu \mathrm{g})$, Cd: Clindamycin $(10 \mu \mathrm{g}), \mathrm{G}$ : Gentamycin $(10 \mu \mathrm{g})$, Nf: Nitrofurantoin $(100 \mu \mathrm{g}), \mathrm{P}$ : Penicillin G (2 Units), K: Kanamycin $(30 \mu \mathrm{g})$.

In PCR, invA, tyv, fliC-d and viaB genes were targeted for the virulence based identification of $S$. enterica serovar Typhi which revealed the $100 \%$ detection of all the above virulence genes from the clinical isolates originated from typhoidial human origins. Although, the pathogenesis of Salmonella has been mediated by several virulence factors, the role of invA gene was significant as this gene helped $S$. Typhi for adhesion and invasion to the host epithelial cells (Darwin and Miller, 1990). This study demonstrated that invA gene was predominant along with the other three genes among the isolates of $S$. Typhi, which could be used as specific marker gene for the rapid detection of the $S$. Typhi isolates from various biological samples irrespective of sample origin (Chiu and Ou, 1996). In analogy, $100 \%$ detection frequency of inv gene among $S$. enterica serovars such as Typhi, Virchow, Enteritidis, Typhimurium, Senftenberg, Strasbourg and Infantis (Kumar et al., 2006) originated from poultry products, wastewater and human sources were reported in other countries (Swamy et al., 1996; Salehi et al., 2005) and also in India (Shome et al., 2006; Ganeshkumar et al., 2010). In mPCR study, the $O$ antigen coded by tyv gene, $\mathrm{H}$ antigen coded by fliC-d and $\mathrm{VI}$ antigen coded by viaB virulence genes were used as the basis of identification of $S$. enterica serovar Typhi from the clinical cases of typhoid fever in humans. The mPCR result depicted in this study established that these three genes are highly conserved among the isolates of $S$. Typhi and could be very useful marker genes for the rapid detection of only $S$. Typhi isolates (Hirose et al., 2002; Kumar et al., 2006).

The result of antibiotic susceptibility test revealed that isolates of S. Typhi were $100 \%$ resistant to ampicillin, $81.25 \%$ to cefuroxime and $68.75 \%$ resistant to penicillin$\mathrm{G}$ and cephalothin respectively. The ampicillin resistant $S$. 


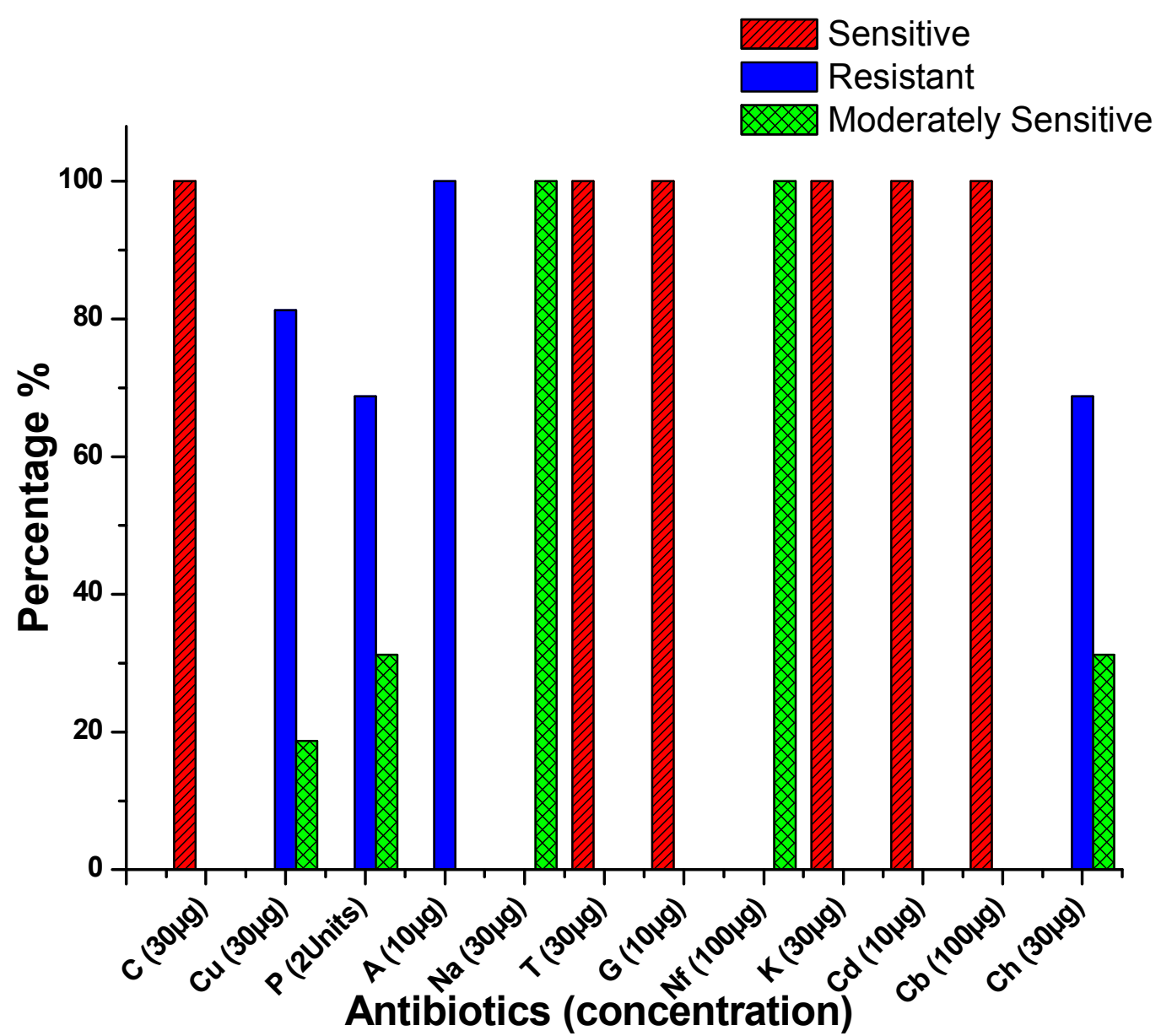

Figure 4: Antibiotic susceptibility test results of $S$. enterica serovar Typhi

A:Ampillicin, C:Chloramphenicol, Cb:Carbenicillin, Cd:Clindamycin, Ch:Cephalothin, Cu:Cefuroxime, G:Gentamycin, K:Kanamycin, Na:Nalidixic acid, Nf:Nitrofurantoin, P:Penicillin G, T:Tetracycline

Typhi isolates from the typhoidial patients from Tamil Nadu, India were reported earlier (Ganeshkumar et al., 2010). The present result clearly indicating the tendency of the $S$. Typhi isolates to become resistance towards multiple drugs. In view of this, researchers from southern Vietnam reported that $90 \%$ S. Typhi isolates were resistant to multiple antibiotics like ampicillin, chloramphenicol and co-trimoxazole (Smith et al., 1994). In India, $29.47 \%$ and $28.42 \%$ of $S$. Typhi isolates were also reported to be resistant to ampicillin and chloramphenicol respectively (Nagshetty et al., 2010). Although, chloramphenicol which has been reported many a times by the researcher as resistance to $S$. Typhi isolates (Agarwal, 1962; Olarte and Galindo, 1973) now found $100 \%$ sensitive in this study along with kanamycin, clindamycin, carbenicillin, gentamycin and tetracycline. In congruence, $100 \%$ sensitivity of $S$. Typhi isolates against chloramphenicol, gentamicin and tetracycline were also detected earlier (Quintaes et al., 2002). This is in full agreement with the reports of re-emergence of sensitivity of S. Typhi to chloramphenicol (Sood et al., 1999). In our study, nalidixic acid and nitrofurantoin were found $100 \%$ moderate. More recently, $76 \%$ of blood culture isolates of $S$. Typhi were reported to be resistant to nalidixic acid (Parry et al., 1998).

\section{CONCLUSION}

This study confirmed the association of virulent strains of Salmonella enterica serovar Typhi in the occurrence of the typhoidial fever in humans in Tamil Nadu. It is suggested from the present study that PCR technique could be a useful, high throughput and rapid diagnostic tool for the detection of $S$. enterica serovar Typhi and could be employed by the diagnostic laboratories or clinics for the clinical diagnosis of typhoidial fever from patients. Despite the use of only 12 antibiotics for susceptibility test, present findings helped to know the current status of typhoidial fever among the people in Southern part of India. Although chloramphenicol and other antibiotics showed $100 \%$ sensitivity, still continuous evaluation of sensitivityresistance pattern of $S$. Typhi isolates is necessary to make rational use of antibiotics in the management of typhoidial fever in future. 


\section{REFERENCES}

Agarwal, S. C. (1962). Chloramphenicol resistance of Salmonella species in India, 1956-61. The International Journal of Public Health - World Health Organization 17: 331-335.

Bauer, A. W., Kirby, W. M. M, Sheris, J. C. and Turck, M. (1996). Antibiotic suspectibility test by standardized single disk method. American Journal of Clinical Pathology 36: 493-496.

Chitnis, V. D., Verma, C. S. and Hemvani, N. (1999). Multidrug-resistant Salmonella typhi in India. Lancet 354: 514-515.

Chiu, C. H. and Ou, J. T. (1996). Rapid identification of Salmonella serovars in faeces by specific detection of virulence genes, invA and spvC, by an enrichment broth culture-multiplex PCR combination assay. Journal of Clinical Microbiology 34: 2619-2622.

Darwin, K. H. and Miller, V. L. (1990). Molecular basis of interaction of Salmonella with the intestinal mucosa. Clinical Microbiology Reviews 12: 405-4428.

Ganeshkumar, A. Shalini, U. Vaishnavi, K. Remya Ismail. Lakshmanaswamy, A. Vasanthi, N. S. and Das, A. (2010). Rapid detection of Salmonella enterica serovar Typhi from humans. Journal of Pure and Applied Microbiology 4: 837-841.

Hashimoto, Y., Itho, Y., Fujinaga, Y., Khan, A. Q., Sultana, F., Miyake, M., Hirose, K., Yamamoto, H. and Ezaki, T. (1995). Development of nested PCR based on the ViaB sequence to detect Salmonella typhi. Journal of Clinical Microbiology 33: 775-777.

Hirose, K., Itoh, K. I., Nakajima, H., Kurazono, T., Yamaguchi, M., Moriya, K., Ezaki, T., Kawamura, Y., Tamura, K. and Watanabe, H. (2002). Selective amplification of tyv ( $\mathrm{rbE})$, prt ( $\mathrm{rfbS})$, viaB, and fliC genes by multiplex PCR for identification of Salmonella enteric Serovars Typhi and Paratyphi A. Journal of Clinical Microbiology 40: 633-636.

Hirose, K., Tamura, K., Sagara, H. and Watanabe, H. (2001). Antibiotic susceptibilities of Salmonella enterica serovar Typhi and $S$. enterica serovar Paratyphi A isolated from patients in Japan. Antimicrobial Agents and Chemotheraphy 45: 956958.

Holt, J. C., Kreig, N. R., Sneath, P. H. A. and Stanley, J. Y. (1994). Bergey's Manual of determinative Bacteriology. Springer. USA. pp 764-799.

Ivanoff, B. and Levine, M. M. (1997). Typhoid fever: continuing challenges from a resilient foe. Bulletin de I'Institut Pasteur 95: 129-142.

Kristensen, M. (1938). Studies on the type division of the typhoid and paratyphoid $B$ bacilli by fermentations. The Journal of Hygiene 38: 688.

Kristensen, M. and Henriksen, H. C. D. (1926). Reactions fermentatives du bacille typhique et leur rôle epidémiologique. Acta Pathologica Microbiologica Scandinavica 3: 551-582.

Kumar, S., Balakrishna, K. and Batra, H. V. (2006). Detection of Salmonella enterica Serovar Typhi ( $S$.
Typhi) by selective amplification of invA, viaB, fliC-d and prt genes by polymerase chain reaction in multiplex format. Letters in Applied Microbiology 42: 149-154.

Lin, F. C., Ho V. A., Bay, P. V., Thuy N. T. T., Bryla, D., Thanh, T. C., Khiem, H. B., Trach, D. D. and Robbins, J. B. (2000). The epidemiology of typhoid fever in the Dong Thap Province, Mekong Delta region of Vietnam. The American Society of Tropical Medicine and Hygiene 62(5): 644-648.

Nagshetty, K., Channappa, S. T. and Gaddad, S. M. (2010). Antimicrobial susceptibility of Salmonella Typhi in India. The Journal of Infection in Developing Countries 4(2):070-073.

Olarte, J. and Galindo, E. (1973). S. typhi resistant to chloramphenicol, ampicillin and other antimicrobial agents: strains isolated in extensive typhoid fever epidemic in Mexico. Antimicrobial Agents in Chemotherapy 4: 597-601.

Old, D. C. and Threlfal, E. J. (1998). Salmonella In: Topley and Wilson's Microbiology and Microbial Infections, 9th edition, volume 2 (Systemic Bacteriology), Arnold, London. pp. 969-97.

Parry, C., Wain, J., Chinh, N. T., Vinh, H., Farrah, J. J. (1998). Quinoloneresistant $S$. typhi in Vietnam. Lancet 351: 1289.

Quintaes, B. R., Leal, N. C., Reis, E. M. F., Fonseca, E. L. and Hofer, E. (2002). Conventional and molecular typing of Salmonella Typhi strains from Brazil. Journal of the Institute of Tropical Medicine of São Paulo 44: 315-319.

Rao, P. S., Rajashekar, V., Varghese, G. K. and Shivananda, P. G. (1993). Emergence of multidrugresistant Salmonella typhi in rural southern India. The American Journal of Tropical Medicine and Hygiene 48:108-111.

Salehi, Z., Mahzounieh, M. and Saeedzadeh, A. (2005). Detection of invA gene in isolated Salmonella from broilers by PCR method. International Journal of Poultry Science 4: 557-559.

Senthilkumar, B. and Prabakaran, G. (2005). Multidrug resistant Salmonella Typhi in asymptomatic Typhoid carriers among food handlers in Namakkal District, Tamilnadu. Indian Journal of Medical Microbiology 23: 92-94.

Shome, B. R., Rahman, H., Shome, R., Murugkar, H. V., Mazumder, Y., Das, A., Kumar, A. and Bujarbaruah, K. M. (2006). Detection of virulent genes and genotyping of Salmonella enterica isolated from livestock and poultry. Indian Veterinary Journal 83: 934-938.

Smith, M. D., Doung, N. M., Hoa, N. T., Wain, J., Ha, H. D., Diep, T. S., Day, N. T., Hien, T. T. and White, N. J. (1994). Comparison of ofloxacin and ceftriaxone for short-course treatment of enteric fever. Antimicrobial Agents and Chemotherapy 38: 1716-1720.

Sood, S., Kapil, A., Das, B., Jain, Y. and Kabra, S. K. (1999). Reemergence of chloramphenicol sensitive Salmonella typhi. Lancet 353: 1241-1242.

Swamy, S. C., Barnhart, H., Lee, M. D. and Dreesen, D. 
W. (1996). Virulence determinants invA and spvC in Salmonellae isolated from poultry products, wastewater and human sources. Applied and Environmental Microbiology 62: 3768-3771.

Verma, N. and Reeves, P. (1989). Identification and sequence of rfbS and $\mathrm{rfbE}$, which determine antigenic specificity of group $A$ and group $D$ salmonellae. Journal of Bacteriology 171: 5694-5701.

Wain, J., Diep, T. S., Ho, V. A., Walsh, A. M., Hoa, N. T. T., Parry, C. M. and White, N. J. (1998). Quantitation of Bacteria in Blood of Typhoid Fever Patients and Relationship between Counts and Clinical Features, Transmissibility and Antibiotic Resistance. Journal of Clinical Microbiology 36: 16831687.

Yonekura, K., Yonekura, S. M. and Namba, K. (2003). Complete atomic model of the bacterial flagellar filament by electron cryomicroscopy. Nature 424: 643-650. 